\title{
Role of macroalgal structure in the distribution and abundance of a temperate reef fish
}

\author{
Todd W. Anderson* \\ Department of Biological Sciences and Marine Science Institute, University of California, Santa Barbara, \\ California 93106, USA
}

\begin{abstract}
Habitat structure can dramatically influence patterns of distribution and abundance of reef fishes. On temperate reefs, much of this structure consists of macroalgae, especially large kelps. I explored the role of such algae, and in particular the structural features of the giant kelp Macrocystis pyrifera, in the distribution and abundance of the kelp perch Brachyistius frenatus. Several measures of the abundance of $M$. pyrifera were positively related to the density of kelp perch. An ontogenetic shift in habitat use occurred within reefs in that young resided initially within the floating surface kelp canopy, older juveniles descended into the water column and became more loosely associated with bundles of fronds, and adults were distributed more uniformly among several defined depth strata. The density of juveniles varied widely both spatially and temporally, which was linked to variation in the percentage cover of the kelp canopy. Not surprisingly, the density of juvenile kelp perch among reefs was related to the density of adults, since young are born directly into the reef habitat. However, the densities of 1 yr old adults on reefs did not reflect the densities of that cohort as juvenile recruits the previous year, possibly due to temporal variation in the abundance of $M$. pyrifera. The hypothesis that macroalgal structure may better predict recruitment strength for algal-associated reef fishes that are capable of only limited dispersal than for those that are first subjected to a planktonic dispersive phase was not supported here. However, to make such comparisons between species, recruitment should be measured concurrently under the same environmental conditions and fluctuations in macroalgal abundance, and the particular relationships between recruiting species and the structural features of macroalgae must be considered.
\end{abstract}

KEY WORDS: Habitat structure $\cdot$ Giant kelp $\cdot$ Reef fish $\cdot$ Kelp perch

\section{INTRODUCTION}

Many reefs in temperate zones support large stands of macroalgae that constitute sizable physical structure. The abundance, distribution, and structural characteristics of such algae, particularly large kelps, exhibit substantial variation both spatially and temporally (Dayton 1985, Schiel \& Foster 1986, Nisbet \& Bence 1989), and it is this variation that may contribute importantly to the dynamics of several temperate reef fishes. For instance, spatial and temporal variation in the recruitment of young-of-year kelp bass Paralabrax clathratus corresponds with variation in the abundance of the giant kelp Macrocystis pyrifera (Carr

\footnotetext{
- Present address: Friday Harbor Laboratories, University of Washington, 620 University Road, Friday Harbor, Washington 98250 , USA
}

1994). Likewise, spatial variation in the recruitment of the labrid Tautogolabrus adspersus coincides with patterns of occurrence and dispersion of macroalgae (Levin 1993). Similar relationships have also been found between temporal variation in the abundance of 2 viviparous surfperches and variation in the occurrence of understory algae (Holbrook et al. 1983, in press). Such correspondence between algal structure and the recruitment of young of at least some fish species may be important in determining subsequent patterns of the distribution and abundance of reefbased adult populations (Doherty \& Williams 1988, Mapstone \& Fowler 1988).

Macrocystis pyrifera is a dominant macroalga along coastal regions of North and South America and elsewhere (Womersley 1954). Conspicuous forests are created by fronds that extend upward from holdfasts on the reef bottom to produce a canopy at the water 
surface. The direct and indirect influence of $M$ pyrifera on the distribution and abundance of fishes has been investigated several times through descriptive or observational studies (Limbaugh 1955, Quast 1968, Bray \& Ebeling 1975, Coyer 1979, Ebeling et al. 1980a, b, Larson \& DeMartini 1984, Stephens et al. 1984, Patton et al. 1985, Bodkin 1986, Ebeling \& Laur 1988, DeMartini \& Roberts 1990, Holbrook et al. 1990, Schmitt \& Holbrook 1990, Carr 1991a, 1994) and experimental manipulation (Moreno \& Jara 1984, Bodkin 1988, Carr 1989, 1991a, 1994). In almost all cases, the abundance of $M$. pyrifera has had an impact, either positive or negative, on the abundance of local fish assemblages (but see Stephens et al. 1984 and Patton et al. 1985). However, the effects of particular structural features of $M$. pyrifera forests (e.g. floating surface canopy, vertical bundles of fronds) on reef fishes are poorly understood

Here I examine the role of macroalgae, and in particular the structure of Macrocystis pyrifera, in the spatial and temporal patterns of distribution and abundance of the kelp perch Brachyistius frenatus (Embiotocidae). The kelp perch is an excellent subject for the study of fish-macroalgal relations. First, it is a species that appears to have one of the strongest associations with and fidelity to $M$. pyrifera (Quast 1968, Coyer 1979, Ebeling et al. 1980a). Previous studies have shown that the presence or density of $M$. pyrifera does influence the abundance of kelp perch (Bray \& Ebeling 1975, Coyer 1979, Larson \& DeMartini 1984, Carr 1989, DeMartini \& Roberts 1990 ) but these studies were conducted over relatively small spatial and temporal scales or did not consider in detail the age-class composition of kelp perch, the many structural features of $M$. pyrifera, or the influence of other macroalgae. Secondly, kelp perch reach maturity within 1 yr of birth (Baltz 1984) and live no more than 2 to $3 \mathrm{yr}$ (Hubbs \& Hubbs 1954), so that a reasonable period of study can encompass the complete life span of a cohort. The longevity of an organism is important for assessment of the contribution of recruitment (input of young) to adult population size. A strong link between recruitment and adult numbers may be masked in longlived populations by the 'storage effect' (Warner \& Chesson 1985) in which the impacts of individual recruitment events are tempered by the enormous reproductive capacities of older and larger females in the adult population. Finally, since surfperches are livebearers that release large, well-developed young directly into the habitat of adults, macroalgal abundance and structure may better predict levels of recruitment of the kelp perch that are not subject to a planktonic dispersive phase and a potentially variable larval supply.

\section{METHODS}

Study area. Nine rocky reefs where Macrocystis pyrifera occurred and two that initially lacked $M$. pyrifera were surveyed annually by visual transect from 1989 through 1992 at Santa Catalina Island, California, USA ( $\left.33^{\circ} 27^{\prime} \mathrm{N}, 118^{\circ} 29^{\prime} \mathrm{W}\right)$. Reefs designated as 'no kelp' sites in 1989 had no more than a few $M$. pyrifera plants which almost never reached the water surface. These reefs were the only ones within several kilometers that did not support stands of $M$. pyrifera, but they did not appear to differ qualitatively from 'kelp' reefs except that bottom depths did not extend below 7 to $8 \mathrm{~m}$. Three additional reefs with $M$. pyrifera were censused in 1991. Reefs typically sloped downward from shallow areas dominated by cover of the understory alga Sargassum palmeri, extending through forests of $M$. pyrifera and ending in a deep-water algal assemblage often dominated by Laminaria farlowil. The reef sites were located over a distance of approximately $12 \mathrm{~km}$ on the northeast side of the island. Surveys were conducted over a $4 \mathrm{wk}$ period in July and August each year, after the main period of parturition by kelp perch had been completed.

Sampling design. Each reef was surveyed once per year on a single day. To address the repeatability and variability of underwater fish censusing techniques (e.g. Sale \& Douglas 1981, McCormick \& Choat 1987. Davis \& Anderson 1989, Lincoln Smith 1989), each of the 11 reefs was censused twice within a $2 \mathrm{wk}$ period in 1989 so that the precision of within-reef density estimates could be examined.

Within the Macrocystis pyrifera forest at each reef, transects were swum in each of 3 strata according to depth: canopy, midwater, and bottom. Eight transects were performed on the bottom, and 6 to 8 transects each were completed within midwater and canopy strata, depending upon the areal extent of the surface kelp canopy. At reefs where $M$. pyrifera was absent or sparse, the midwater and canopy regions were sampled by looking upward from bottom transects. Shallow-bottom ( $3 \mathrm{~m}$ depth) and deep-bottom (18 to $24 \mathrm{~m}$ depth) strata that had characteristic algal assemblages also were sampled. Transect dimensions for all surveys were $2 \mathrm{~m}$ high $\times 2 \mathrm{~m}$ wide $\times 30 \mathrm{~m}$ long for a total volume of $120 \mathrm{~m}^{3}$. All surveys were conducted between 08:30 and 16:30 h Pacific Daylight Savings Time (PDT) and horizontal visibility always exceeded $7 \mathrm{~m}$.

At each reef, the deep-bottom area was sampled first. The dominant algae here were Laminaria farlowii and Agarum fimbriatum on rock and Pelagophycus porra over sand. Fish were counted on 4 transects along a depth contour between 18 and $24 \mathrm{~m}$. Kelp perch were enumerated by estimated standard length 
(SL) within age class groupings defined by Coyer (1979) with younger and older juveniles distinguished arbitrarily: young juvenile $(<5 \mathrm{~cm})$, older juvenile $(5$ to $8 \mathrm{~cm}$ ), 1 yr old ( 8 to $12 \mathrm{~cm}$ ), and $2 \mathrm{yr}$ old or older $(>12 \mathrm{~cm}$ ) fish. I also recorded the number of kelp bass Paralabrax clathratus $>15 \mathrm{~cm}$ SL as predators of kelp perch (Anderson 1993). The number of A. fimbriatum, Eisenia arborea, L. farlowii, P. porra, and juvenile (young plants $<2 \mathrm{~m}$ tall) and adult (large, well-developed holdfasts) Macrocystis pyrifera plants were counted on each transect.

Within stands of Macrocystis pyrifera, numbers of kelp perch, kelp bass, and $M$. pyrifera plants were tallied within canopy, midwater, and bottom strata as noted earlier. Four transects each were conducted along the $12 \mathrm{~m}$ and $6 \mathrm{~m}$ depth bottom contours in which the number of juvenile and adult $M$. pyrifera plants was scored. For each canopy transect, the percentage cover of $M$. pyrifera was determined by the number of times that fronds intersected a line between 20 random points at $2 \mathrm{~m}$ depth and the surface (GreigSmith 1983). After each midwater transect (approximately halfway between the surface and bottom) the number of $M$. pyrifera fronds in a $2 \mathrm{~m}$ swath were counted. In shallow-bottom areas, the number of Eisenia arborea and $M$. pyrifera plants were counted along the $3 \mathrm{~m}$ depth contour.

To document seasonal patterns of kelp perch recruitment (density of juveniles), 3 reefs where Macrocystis pyrifera was abundant were surveyed approximately every $10 \mathrm{~d}$ from late April through August 1990. Since kelp perch recruits occur mainly in the canopy and midwater strata, only these regions were sampled. Complete single censuses (all strata surveyed) of the same 3 reefs were conducted in late May and early June 1990, after the onset of parturition to document the distribution of young kelp perch among strata relative to their subsequent distribution at these reefs in July and August.

Analyses. Statistical analyses were performed using PC SAS version 6.03 software (SAS Institute, Inc. 1988). A Spearman's rank correlation coefficient was calculated to test for concordance in the magnitude of differences in fish density among reefs between the first (May-June) and the second (July-August) surveys in 1989. A 1-tailed paired-comparisons $t$-test was used to determine whether there was a significant decrease in fish densities between these surveys; apparent high fidelity to reefs and thus negligible immigration over this short-term period indicated that the density of kelp perch should either remain the same or decrease between surveys. I used a 2-tailed paired-comparisons t-test to detect any differences in measures of Macrocystis pyrifera abundance between surveys.
Fish were absent in some years at reefs without kelp, and thus the assumption of homogeneity of variances could not be met for comparisons with ANOVA. Therefore, a log-likelihood ratio $(G)$ test was used to determine if there were significant differences in the frequency of juvenile and adult fish between 'kelp' and 'no kelp' reefs. Since deep-bottom algal assemblages did not occur at reefs without kelp, fish recorded in these regions at 'kelp' reefs were not included in the analysis. According to significant heterogeneity $\chi^{2}$ tests ( $p<0.001 ;$ Zar 1984) for both juvenile and adult kelp perch, frequencies could not be pooled across years; tests were done separately for each year over the 4 yr period. I also used a $G$-test to compare differences in the frequency of juvenile and adult fish among sampled strata at 3 reefs censused in spring and then again in summer 1990.

For reefs with kelp, a 2-factor mixed model analysis of variance (ANOVA) was used to test for reef (random) and year (fixed) effects on the density of juvenile and adult kelp perch. A Ryan-Einot-Gabriel-Welsch multiple-range test was used to identify which levels of factors were different. Assumptions of normality (Shapiro-Wilk $W$-test) and homogeneity of variances (Cochran's C-test; Winer 1971) were met for adult densities but not for juvenile densities until their transformation $\left[\log _{10}(x+0.15)\right]$. The constant used in the transformation was approximately one-sixth of the minimum non-zero arithmetic value (see Mosteller \& Tukey 1977).

To examine variation in the density of juvenile and adult kelp perch among reefs, multiple regression analyses of independent variables measured concurrently with fish densities were performed. Data were estimates by reef of the percentage cover of the Macrocystis pyrifera canopy and densities of the following variables: $M$. pyrifera fronds, $M$. pyrifera adult and juvenile plants, Agarum fimbriatum, Eisenia arborea, Laminaria farlowii, Pelagophycus porra, kelp bass, and adult kelp perch (for juvenile kelp perch regression models only). The 9 designated 'kelp' reefs were analyzed by year (12 reefs in 1991) and then pooled for an across-year analysis. Although multicollinearity was found between canopy cover, frond density, and adult plant density values of $M$. pyrifera, I used the method of Hocking (1976; also see Zar 1984) to determine the models that best explained variation in the density of kelp perch. A single model from each array of 1 up to the total number of independent variables was identified based upon the highest coefficient of determination $\left(\mathrm{r}^{2}\right)$. From this collection of identified models, a 'best' model was selected based on the lowest Mallows' $C_{p}$ value (Mallows 1973). Stepwise multiple regressions then were run with each 'best' model to determine partial $r^{2}$ values for each variable and thus 
its relative contribution to the explained variation in the density of kelp perch. Densities of juvenile kelp perch were transformed $\left[\log _{10}(x+0.15)\right]$ to meet assumptions of linearity and homogeneity of variances, whereas untransformed values were used for adult densities. Simple correlations were done to examine particular relationships between the abundance of macroalgae and the density of kelp perch.

\section{RESULTS}

\section{Spatial and temporal patterns of abundance}

The number and dimensions of transects yielded good correspondence in juvenile $\left(r_{s}=0.64, n=11, p<\right.$ $0.05)$ and adult $\left(r_{s}=0.95, n=11, p<0.05\right)$ density of kelp perch between surveys at reefs in 1989. The second surveys (July-August) showed similar differences in density among reefs as observed in the first surveys (May-June). Consequently, single censuses performed at reefs in each subsequent year were considered to be highly reliable. Besides concordance between surveys, densities of juvenile kelp perch at reefs with Macrocystis pyrifera were significantly lower on the second survey $(t=4.5, \mathrm{df}=9, \mathrm{p}=0.001)$ while adult densities showed no such decline $(t=$ $-0.29, \mathrm{df}=9, \mathrm{p}=0.39$ ). A total of 8 of the 9 reefs had lower juvenile densities on the second survey, suggesting that a reduction in density at any particular reef was unlikely to be a result of inter-reef movements of fish. The decrease in juvenile densities, however, was not accompanied by a reduction in $M$. pyrifera abundance. Both percentage canopy cover and frond

Table 1. Brachyistius frenatus. Log-likelihood ratio tests for differences in the annual frequencies of juvenile and adult kelp perch among reefs (n) selected initially with ('kelp') and without ('no kelp') Macrocystis pyrifera. ' $\mathrm{n}=1$ reef because one of the 2 'no kelp' reefs supported a large stand of $M$. pyrifera in 1992 and was excluded from analysis

\begin{tabular}{|c|c|c|c|c|c|}
\hline Year & $\begin{array}{c}\text { 'Kelp' } \\
\text { reefs } \\
(n=9)\end{array}$ & $\begin{array}{c}\text { 'No kelp' } \\
\text { reefs } \\
(\mathrm{n}=2)\end{array}$ & $\mathrm{df}$ & $\begin{array}{c}\text { Test } \\
\text { statistic } \\
(G)\end{array}$ & $\mathrm{p}$ \\
\hline \multicolumn{6}{|c|}{ Juvenile frequencies } \\
\hline 1989 & 2367 & 58 & 1 & 593.1 & $<0.001$ \\
\hline 1990 & 2679 & 27 & 1 & 867.2 & $<0.001$ \\
\hline 1991 & 175 & 1 & 1 & 61.6 & $<0.001$ \\
\hline 1992 & 119 & $0^{\circ}$ & 1 & 136.3 & $<0.001$ \\
\hline \multicolumn{6}{|c|}{ Adult frequencies } \\
\hline 1989 & 430 & 3 & 1 & 146.7 & $<0.001$ \\
\hline 1990 & 310 & 2 & 1 & 106.5 & $<0.001$ \\
\hline 1991 & 256 & 23 & 1 & 22.6 & $<0.001$ \\
\hline 1992 & 90 & $0^{\circ}$ & 1 & 18.9 & $<0.001$ \\
\hline
\end{tabular}

JUVENILES
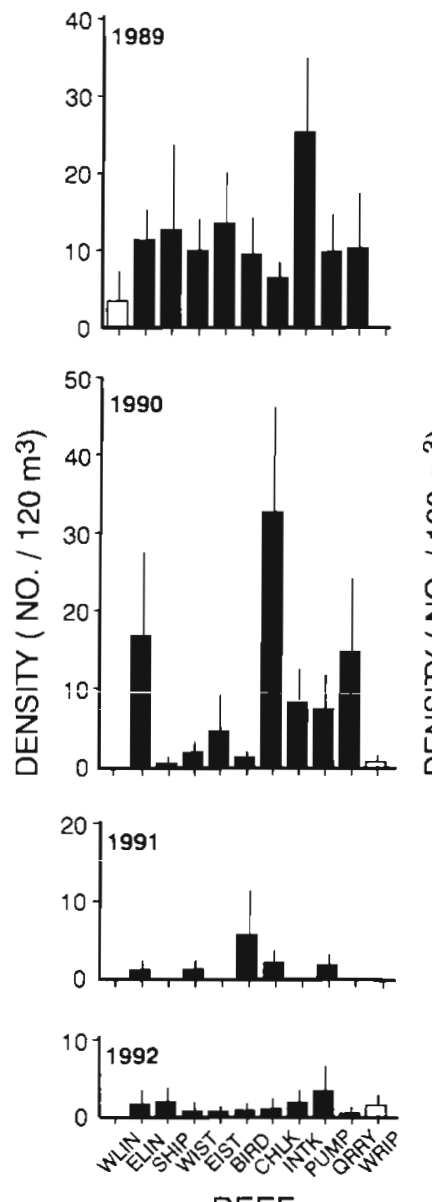

REEF

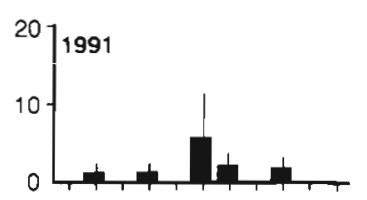

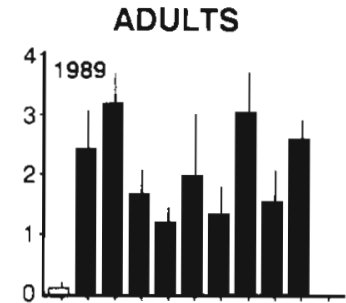
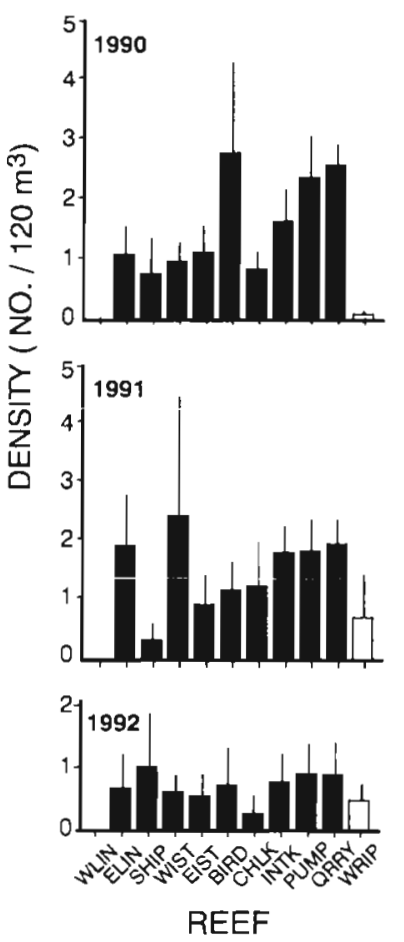

Fig. 1. Brachyistius frenatus. Densities (no. of fish per $120 \mathrm{~m}^{3}$ ) of juvenile and adult kelp perch at 11 reefs from 1989 to 1992. Data are mean densities from up to 5 defined depth strata sampled $_{i}$ error bars $=1 \mathrm{SE}$. Solid and open histograms represent reefs initially with and without Macrocystis pyrifera, respectively. Reef acronyms denote the following reefs: WLIN, West Lionhead Point; ELIN, East Lionhead Point; SHIP, Ship Rock; WIST, West Isthmus Reef; EIST, East Isthmus; BIRD, Bird Rock; CHLK, Chalk Cove; INTK, Seawater Intakes; PUMP, Pumpernickel Cove; QRRY, Quarry; WRIP, West Rippers Cove

density were very similar between the first and second surveys (62 vs $65 \%$ cover, $t=-1.02, \mathrm{df}=9, \mathrm{p}=0.34$; 338 vs 332 fronds per $60 \mathrm{~m}^{2}, t=0.03, \mathrm{df}=9, \mathrm{p}=0.98$ ).

The most basic pattern observed was that the kelp perch was present and often abundant on reefs with Macrocystis pyrifera but was generally scarce on reefs where M. pyrifera was sparse or lacking (Fig. 1). Highly significant differences (Table 1 ) in the densities of juvenile and adult fish between 'kelp' and 'no kelp' reefs were found despite great temporal variation in M. pyrifera abundance at 'kelp' reefs. In 1992, one of the 'no kelp' reefs supported a large stand of $M$. 
Table 2. Brachyistius frenatus. Annual estimates of abundance for juvenile and adult kelp perch and for Macrocystis pyrifera. Mean density (fish per $120 \mathrm{~m}^{3}$ ) \pm 1 SE and coefficient of variation (CV) for kelp perch were calculated from surveys of 'kelp' reefs $(n=9)$ surveyed annually. Percentage canopy cover and frond density $( \pm 1$ SE) of $M$. pyrifera were derived from these same reefs over the 4 yr period

\begin{tabular}{|crccccc|}
\hline \multirow{2}{*}{ Year } & \multicolumn{2}{c}{ Density } & \multicolumn{2}{c}{ CV } & Canopy & $\begin{array}{c}\text { Frond } \\
\text { density }\end{array}$ \\
\hline & Juveniles & Adults & Juveniles & Adults & & \\
1989 & $12.3(1.76)$ & $2.1(0.24)$ & 0.43 & 0.34 & $61.8(4.50)$ & $332(20.4)$ \\
1990 & $10.0(3.45)$ & $1.6(0.26)$ & 1.03 & 0.50 & $53.8(5.39)$ & $420(32.2)$ \\
1991 & $1.5(0.61)$ & $1.5(0.28)$ & 1.20 & 0.43 & $29.9(7.26)$ & $237(34.4)$ \\
1992 & $1.5(0.31)$ & $0.7(0.08)$ & 0.61 & 0.32 & $40.9(10.6)$ & $383(41.1)$ \\
\hline
\end{tabular}

pyrifera and had much higher numbers of kelp perch (42 juveniles and 12 adults); therefore, it was removed from analysis as a 'no kelp' reef. For 'kelp' reefs, densities of both juvenile and adult kelp perch varied among years but not reefs, with no year-reef interaction (2-factor ANOVA, juveniles: year effect, $F_{3,24}=$ $26.63, \mathrm{p}=0.0001$; reef effect, $F_{8,132}=1.02, \mathrm{p}=0.42$; year $\times$ reef interaction, $F_{24,132}=0.79, p=0.75$; adults: year effect, $F_{3,24}=9.14, \mathrm{p}=0.0003$; reef effect, $F_{8,132}=1.39$, $\mathrm{p}=0.20$; year $\times$ reef interaction, $F_{24,132}=0.81, \mathrm{p}=0.72$ ). Densities of juvenile kelp perch were higher in 1989 and 1990 than in subsequent years while adult densities were similar except for 1992 when they were significantly lower. The percentage kelp canopy cover declined from 1989 to 1991, while frond densities varied over the 4 yr period (Table 2). The lack of differences in juvenile densities among reefs appears to be a

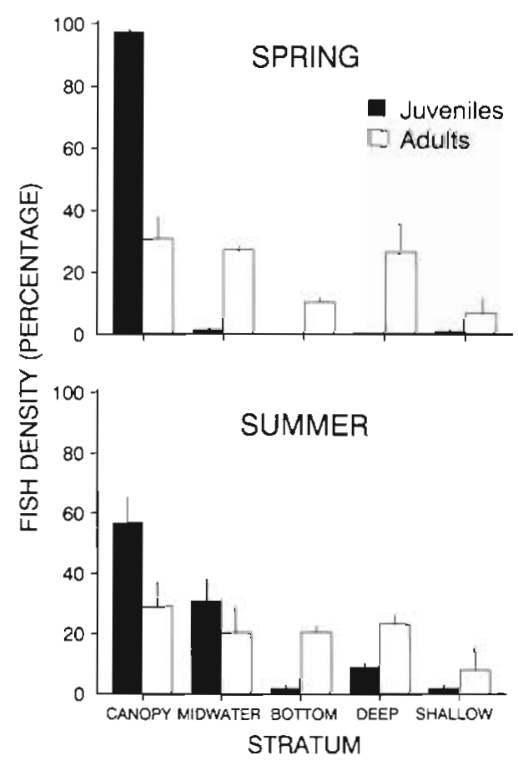

Fig. 2. Brachyistius frenatus. Distribution of juvenile and adult kelp perch among defined depth strata surveyed in the spring and in the summer of 1990 . Data are mean percentages of densities (no. of fish per $120 \mathrm{~m}^{3}$ ) within strata at 3 reefs (ELIN, INTK, QRRY); error bar $=1 \mathrm{SE}$ result of substantial within-reef variation in density among years. Adult densities were more uniform among reefs and years and varied less than their juvenile counterparts (Table 2 ).

There were obvious differences in the distribution of juvenile and adult kelp perch among strata at 3 reefs sampled twice in 1990 (Fig. 2). Both life stages showed significant differences between the frequencies of fish among strata in both spring (juveniles: $G=7588.77$. $\mathrm{df}=3$ (bottom stratum excluded because of zero fish), $\mathrm{p}<0.001$; adults: $G=137.54$, df $=4, \mathrm{p}<0.001)$ and summer (juveniles: $G=1919.50, \mathrm{df}=4, \mathrm{p}<0.001$; adults: $G=14.85$, $\mathrm{df}=4, \mathrm{p}<0.01$ ). In spring, young kelp perch occurred almost exclusively in the kelp canopy at mean densities of up to 142 fish per $120 \mathrm{~m}^{3}$, whereas in summer, the proportion of juveniles had increased greatly in the midwater stratum. This increase coincided with an increase in body size of the juvenile cohort; in spring, only $3.8 \%$ of juveniles tallied on transects were older juveniles ( 5 to $8 \mathrm{~cm} \mathrm{SL}$ ) as compared to $39.3 \%$ in summer. Adults exhibited a much more even distribution among strata in both spring and summer than did juveniles, as evidenced by much lower test statistic values.

Densities of juvenile kelp perch measured at ELIN, INTK, and QRRY 'kelp' reefs increased greatly in May, leveled off in June, and eventually declined in late July and August 1990. This pattern was similar qualitatively in other years, although timing of recruitment varied by approximately 1 mo or more among years (pers. obs.). As the proportion of recruits declined in the canopy, it increased in midwater, coinciding with the increase in the proportion of older juveniles during the recruitment period (Fig. 3).

Spatially, juvenile densities were positively related to adult densities at reefs within years (Fig. $4 \mathrm{~A}_{i} \mathrm{r}=$ 0.47, df $=38, p=0.003$ ). The age structure of kelp perch was such that 2 yr old or older fish constituted only a small percentage of adult densities (mean of $4 \mathrm{yr}$ $\pm 1 \mathrm{SE}=10.2 \pm 2.69 \%$ ). Thus 1 yr old fish accounted for the bulk of adult abundance. The relationship between juvenile density and the density of 1 yr old fish at reefs 


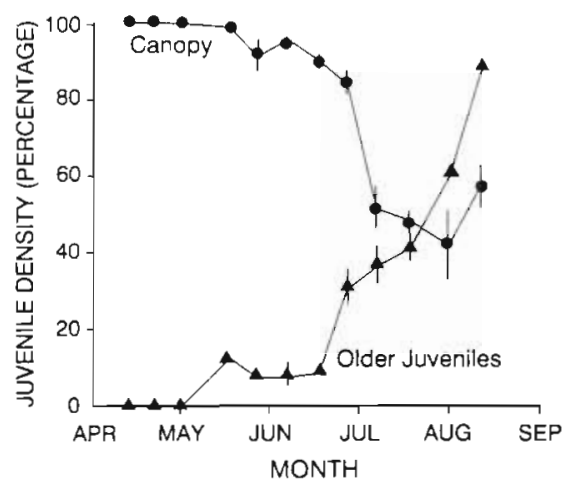

Fig. 3. Brachyistius frenatus. Percentage of juvenile fish in the Macrocystis pyrifera canopy (•) and percentage of older juveniles (50 to $80 \mathrm{~mm}$ standard length, $\boldsymbol{\Delta}$ ) of total juvenile densities (no. of fish per $120 \mathrm{~m}^{3}$ ) from April through August 1990 at 3 reefs (ELIN, INTK, QRRY). Error bars $=1 \mathrm{SE}$
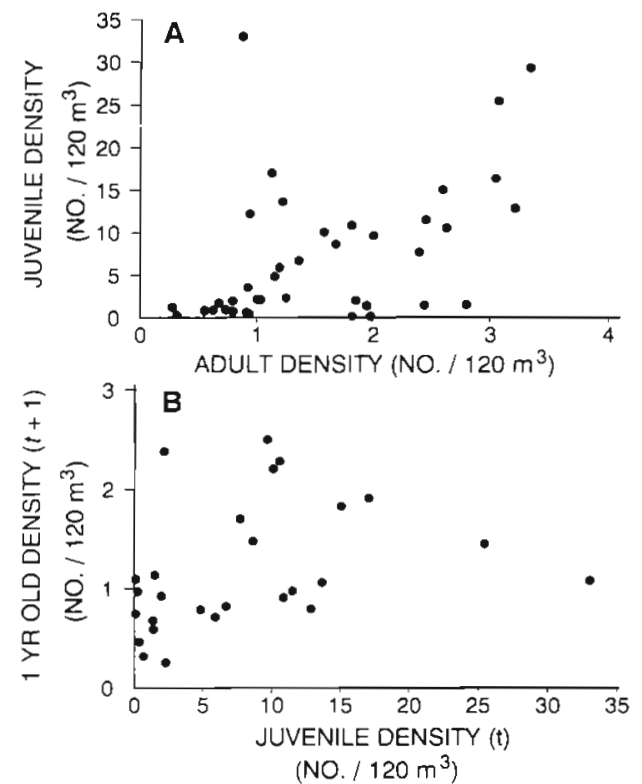

Fig. 4. Brachyistius frenatus. Relationship between (A) densities (no. of fish per $120 \mathrm{~m}^{3}$ ) of adult and juvenile kelp perch among reefs $(n=39)$ from 1989 to 1992, and $(B)$ the density of juvenile kelp perch at reefs in $1 \mathrm{yr}(\mathrm{t})$ and the density of that cohort as 1 yr old fish at the same reefs $(n=27)$ the next year

$$
(t+1)
$$

the following year was positive but not significant statistically among reefs (Fig. $4 \mathrm{~B}_{i} r=0.33, \mathrm{df}=26, \mathrm{p}=$ $0.09)$ or years $(r=0.99, \mathrm{df}=2, \mathrm{p}=0.10)$.

\section{Fish density and macroalgal structure}

Stepwise multiple regressions of the models that best explained variation in kelp perch density (those with the highest $r^{2}$ but lowest $C_{p}$ values) showed that the structural features of Macrocystis pyrifera explained much of the variation in the density of juvenile kelp perch (Table 3). $M$. pyrifera was important in the distribution of adults but constituted less of the explained variation than for juveniles (Table 3). The regression models of all years combined showed that the cover of the $M$. pyrifera canopy was important in explaining variation in the density of both life stages. In addition to macroalgae, the density of kelp bass occurred in regression models of all years combined and had a negative relationship with both juvenile and adult kelp perch. Overall, the total explained variation was higher within and among years for juveniles than for adults.

The density of juvenile kelp perch was strongly and positively related to several structural features of Macrocystis pyrifera. Recruit densities were related to M. pyrifera canopy cover (Fig. 5A; $\mathrm{r}=0.65$, df $=38, \mathrm{p}=$ 0.0001 ) such that numbers of fish were negligible below a 'threshold' value of about $45 \%$ cover, after which they increased dramatically. Similarly, juvenile kelp perch increased greatly in number at frond densities of 300 to 400 per $60 \mathrm{~m}^{2}$ (Fig. $5 \mathrm{~B} ; \mathrm{r}=0.51$, df $=38, \mathrm{p}=$ 0.001 ) and at densities of approximately 12 adult plants per $60 \mathrm{~m}^{2}$ (Fig. 5C; $\mathrm{r}=0.46$, $\mathrm{df}=38, \mathrm{p}=0.004$ ). The density of adult kelp perch also was correlated with

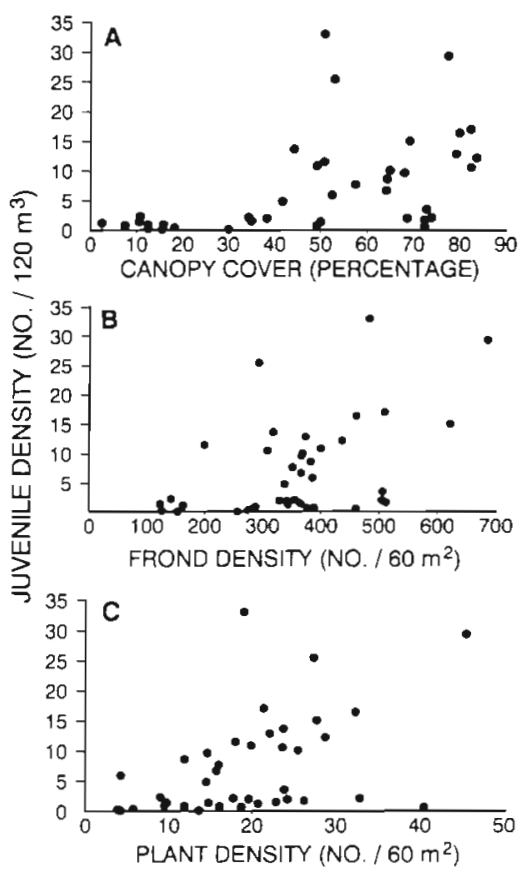

Fig. 5. Brachyistius frenatus. Relationship between the density (no. of fish per $120 \mathrm{~m}^{3}$ ) of juvenile kelp perch and Macrocystis pyrifera (A) percentage canopy cover, $(B)$ frond density, and (C) adult plant density among reefs ( $\mathrm{n}=39$ ) from 1989 to 1992 
Table 3. Brachyistius frenatus. Stepwise multiple regression models of among-reef sources of variation for juvenile and adult densities of kelp perch. Independent variables measured as density are based on no. of fish per $60 \mathrm{~m}^{2}$. $\mathrm{N}$ : number of 'kelp' reefs surveyed; Macro canopy: percentage cover of Macrocystis pyrifera within $2 \mathrm{~m}$ depth of the surface; Macro. fronds: density of $M$. pyrifera fronds; Adult Macro.: density of M. pyrifera adult plants; Juvenile Macro: density of juvenile $M$. pyrifera $(<2 \mathrm{~m}$ in height); Eisenia: density of Eisenia arborea in shallow-bottom stratum; Laminaria/Agarum: combined density of Laminaria farlowii and Agarum fimbriatum in deep-bottom stratum; Adult kelp perch: density of adult kelp perch; Kelp bass: density of kelp bass ( $>15 \mathrm{~cm}$ standard length). None: no variable met the 0.15 significance level for entry into the model

\begin{tabular}{|c|c|c|c|c|c|c|}
\hline Year & $N$ & Independent variable & Coefficient & Partial $\mathbf{r}^{2}$ & Total $r^{2}$ & $\mathrm{p}$ \\
\hline \multicolumn{7}{|c|}{ Dependent variable: $\log _{10}(j u v e n i l e$ density +0.15$)$} \\
\hline 1989 & 9 & $\begin{array}{l}\text { Adult Macro. } \\
\text { Juvenile Macro. } \\
\text { Adult kelp perch } \\
\text { Macro. fronds }\end{array}$ & $\begin{array}{r}0.023 \\
-0.007 \\
0.082 \\
-0.001\end{array}$ & $\begin{array}{l}0.493 \\
0.196 \\
0.194 \\
0.072\end{array}$ & 0.955 & $\begin{array}{l}0.03 \\
0.10 \\
0.03 \\
0.06\end{array}$ \\
\hline 1990 & 9 & $\begin{array}{l}\text { Juvenile Macro. } \\
\text { Macro, fronds } \\
\text { Kelp bass } \\
\text { Adult kelp perch } \\
\text { Laminaria/Agarum } \\
\text { Macro. canopy }\end{array}$ & $\begin{array}{r}0.018 \\
0.006 \\
-0.239 \\
-0.198 \\
0.007 \\
-0.010\end{array}$ & $\begin{array}{l}0.432 \\
0.420 \\
0.058 \\
0.041 \\
0.032 \\
0.015\end{array}$ & 0.998 & $\begin{array}{l}0.05 \\
0.006 \\
0.14 \\
0.15 \\
0.10 \\
0.06\end{array}$ \\
\hline 1991 & 12 & $\begin{array}{l}\text { Macro. canopy } \\
\text { Juvenile Macro. } \\
\text { Laminaria/Agarum }\end{array}$ & $\begin{array}{r}0.012 \\
-0.014 \\
-0.007\end{array}$ & $\begin{array}{l}0.636 \\
0.131 \\
0.116\end{array}$ & 0.882 & $\begin{array}{l}0.002 \\
0.02 \\
0.07\end{array}$ \\
\hline 1992 & 9 & None & & & & \\
\hline All years & 39 & $\begin{array}{l}\text { Macro. canopy } \\
\text { Kelp bass } \\
\text { Juvenile Macro. }\end{array}$ & $\begin{array}{r}0.014 \\
-0.259 \\
-0.009\end{array}$ & $\begin{array}{l}0.364 \\
0.165 \\
0.068\end{array}$ & 0.598 & $\begin{array}{l}0.0001 \\
0.002 \\
0.03\end{array}$ \\
\hline \multicolumn{7}{|c|}{ Dependent variable: adult density } \\
\hline 1989 & 9 & $\begin{array}{l}\text { Eisenia } \\
\text { Adult Macro. } \\
\text { Macro. canopy }\end{array}$ & $\begin{array}{r}-0.084 \\
0.089 \\
0.024\end{array}$ & $\begin{array}{l}0.302 \\
0.240 \\
0.204\end{array}$ & 0.746 & $\begin{array}{l}0.12 \\
0.13 \\
0.10\end{array}$ \\
\hline 1990 & 9 & $\begin{array}{l}\text { Eisenia } \\
\text { Juvenile Macro. }\end{array}$ & $\begin{array}{r}0.194 \\
-0.052\end{array}$ & $\begin{array}{l}0.437 \\
0.298\end{array}$ & 0.735 & $\begin{array}{l}0.05 \\
0.04\end{array}$ \\
\hline 1991 & 12 & Adult Macro. & 0.044 & 0.442 & 0.442 & 0.02 \\
\hline 1992 & 9 & Macro. canopy & 0.006 & 0.630 & 0.630 & 0.01 \\
\hline All years & 39 & $\begin{array}{l}\text { Macro. canopy } \\
\text { Kelp bass } \\
\text { Eisenia }\end{array}$ & $\begin{array}{r}0.013 \\
-0.396 \\
-0.038\end{array}$ & $\begin{array}{l}0.135 \\
0.138 \\
0.054\end{array}$ & 0.327 & $\begin{array}{l}0.02 \\
0.03 \\
0.12\end{array}$ \\
\hline
\end{tabular}

canopy cover $(\mathrm{r}=0.46 \mathrm{df}=38, \mathrm{p}=0.004)$ but not with other measures of $M$. pyrifera abundance. Moreover, this relationship was linear rather than exponential, unlike those for juvenile fish.

Although there were significant and positive relationships between several structural features of $\mathrm{Mac}$ rocystis pyrifera and the density of juvenile kelp perch, these features themselves were highly correlated. To ascertain which of them directly affected the density of juvenile kelp perch, I selected reefs that were above the threshold density of adult $M$. pyrifera plants $(12$ per $60 \mathrm{~m}^{2}{ }_{i}$ Fig. 5C) at which appreciable densities of fish occurred. I categorized these reefs into high and low fish density, the high density category corresponding to juvenile densities of $>5$ fish per $120 \mathrm{~m}^{3}$. I then compared percentage canopy cover, density of fronds, and density of adult plants of $M$. pyrifera between the 2 categories using $t$-tests. Mean percentage canopy cover ( $\pm 1 \mathrm{SE}$ ) was significantly higher in the high density category $($ high $=66.1 \pm 3.44 \%$, low $=46.4 \pm 6.38 \%$, $t=2.72$, df $=20.2, \mathrm{p}=0.01$, Satterthwaites's approximation of degrees of freedom for unequal variances). Mean percentage canopy cover in the low density category was approximately at the threshold of canopy cover at which numbers of juvenile fish may increase exponentially (Fig. 5a). Mean densities of fronds and adult plants in high and low fish density categories were near or above such threshold values (fronds: high $=409 \pm 30.7$, low $=374 \pm 6.38$; plants: high $=23.8 \pm$ 1.93 , low $=21.9 \pm 2.01$ ), but they were not significantly different between these categories (fronds: $t=0.84$, $\mathrm{df}=28, \mathrm{p}=0.41$; plants: $t=0.70, \mathrm{df}=28, \mathrm{p}=0.49)$. Dif- 


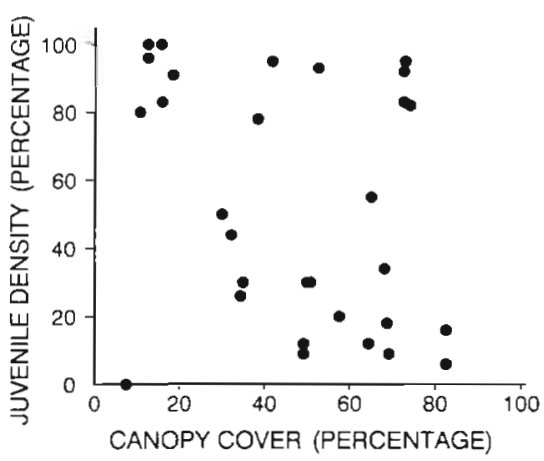

Fig. 6. Brachyistius frenatus. Relationship between the percentage of juvenile kelp perch (no. of fish per $120 \mathrm{~m}^{3}$ ) occupying the Laminaria farlowï/Agarum fimbriatum deepbottom stratum and the percentage cover of Macrocystis pyrifera canopy among reefs $(n=30)$ from 1989 to 1992

ferences in annual density estimates of juvenile kelp perch coincided with the amount of canopy cover. When juvenile densities were high in 1989 and 1990 , mean canopy cover among reefs averaged $62 \%$ and $54 \%$, respectively. In 1991 and 1992, juvenile densities were very low, and mean canopy cover estimates were $30 \%$ and $41 \%$, below the threshold value of canopy cover (see Table 2).

When the cover of the kelp canopy and thus the density of juvenile kelp perch was low, fish exhibited a different distribution among sampled strata. The proportion of juvenile kelp perch on reefs with Laminaria farlowii and Agarum fimbriatum algae tended to be higher in the deep-bottom stratum (Fig. 6; $r=-0.32$, $\mathrm{df}=29, \mathrm{p}=0.09$ ), significantly so when 1 reef that had no fish in the deep-bottom stratum was omitted ( $\mathrm{r}=$ -0.48, df $=28, p=0.02$ ). The deep-bottom alga Pelagophycus porra was abundant in 1989 over sand just outside 2 reefs and supported high juvenile densities of between 9.5 and 28.0 fish per $120 \mathrm{~m}^{3}$. P. porra declined dramatically in subsequent years, along with the density of juvenile kelp perch, and virtually disappeared at 1 site by 1991.

Temporal variation in the abundance of Macrocystis pyrifera coincided with variation in the density of kelp perch. There was a positive relationship between coefficients of variation in the percentage canopy cover of M. pyrifera and coefficients of variation in the density of juvenile kelp perch among the 9 'kelp' reefs sampled over the 4 yr period (Fig. 7 $A_{i} r=0.71$, df $=8, p=$ 0.03 ). I explored further these dynamics at individual reefs over time. There was a significant relationship between the change in the density of $M$. pyrifera fronds (as a general indicator of kelp abundance) at a reef and the associated change in fish density as the difference between the density of juveniles in one year and the density of that cohort at that reef as 1 yr old fish
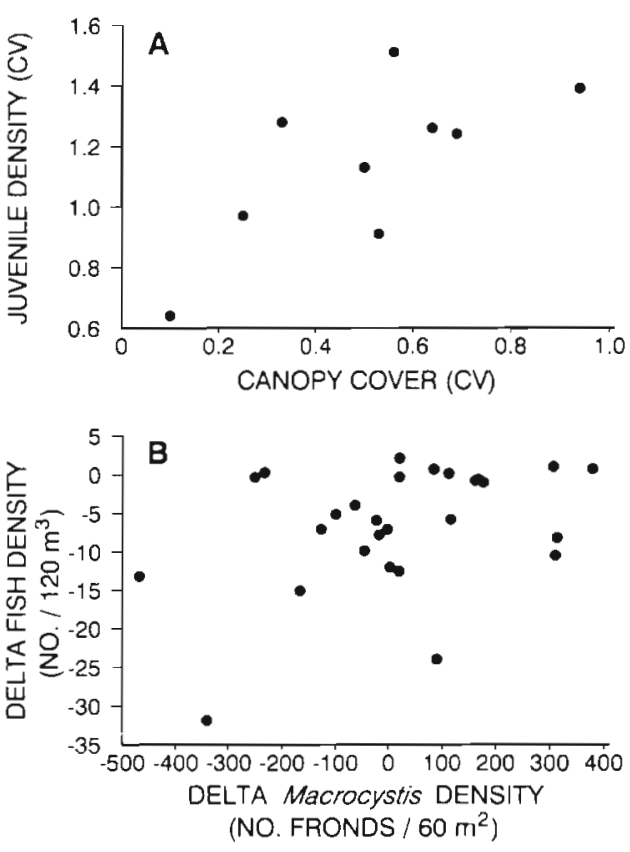

Fig. 7. Brachyistius frend tus. Reldtionship between (A) coefficients of variation (CV) in density (no. of fish per $120 \mathrm{~m}^{3}$ ) of juvenile kelp perch and in the percentage cover of Macrocystis pyrifera canopy at reefs with $M$. pyrifera $(\mathrm{n}=9)$ over 4 years (1989 to 1992), and (B) the change (delta) in M. pyrifera frond density at a reef and the associated change in the density of kelp perch (juvenile to $1 \mathrm{yr}$ old fish) at that reef from one year to the next year $(\mathrm{n}=27)$

the next year (Fig. 7B; $r=0.39, d f=27, p=0.04$ ). This suggests that juveniles experience less mortality on reefs during their first year of life when there is an increase in the abundance of $M$. pyrifera. Variation in frond density, rather than in percentage canopy cover, was used as an appropriate measure of $M$. pyrifera abundance over a 1 yr period since juveniles do not necessarily rely on the kelp canopy after they attain a certain size, and adults are distributed more uniformly throughout the water column.

\section{DISCUSSION}

Many temperate reefs possess lush growths of canopy-forming kelps and other macroalgae. Relationships between algal structure and the abundance and distribution of reef fishes are well documented in some geographic regions (see Ebeling \& Hixon 1991), but how this structure influences the composition of the local fish assemblage as a whole depends on the strength and direction of relationships with individual species. Relationships between the abundance of kelp perch and macroalgae are obvious at the coarsest resolution. Fish occur in appreciable numbers on reefs 
where stands of Macrocystis pyrifera are present, and this has been established in several previous studies (Quast 1968, Bray \& Ebeling 1975, Coyer 1979, Ebeling et al. 1980a, Larson \& DeMartini 1984, Carr 1989).

At a somewhat finer resolution, the density of kelp perch is positively related to Macrocystis pyrifera abundance (Coyer 1979, DeMartini \& Roberts 1990). In this study, juvenile numbers varied considerably among reefs within certain years and within reefs over time, and this variation coincided with temporal variation in the canopy cover of $M$. pyrifera. Relationships between the density of juvenile kelp perch and measures of $M$. pyrifera abundance are non-linear, increasing greatly above threshold values of algae. Coyer (1979) described such a relationship between the density of kelp perch (juveniles and adults combined) and the density of adult $M$. pyrifera plants, and other exponential relationships between numbers of recruiting fish and algae have been noted (Jones 1984a). Multiple regression models and further analysis indicate that above these thresholds, it is the percentage cover of the $M$. pyrifera canopy that determines the density of juvenile kelp perch.

Although the kelp perch has been designated as a canopy or upper water-column dweller (Bray \& Ebeling 1975, Coyer 1979, Ebeling et al, 1980a, b, Larson \& DeMartini 1984), differences in distribution among young recruits, older juveniles, and adults suggest a weakening of specific habitat preferences with age and size. These within-reef differences in distribution correspond to ontogenetic shifts in habitat and food use (for review see Werner \& Gilliam 1984). Food and shelter derived from macroalgal structure are cited, often collectively, as important resources for temperate reef fish assemblages. This assertion appears at least circumstantially correct, although decoupling the relative importance of food versus shelter to reef fishes (Jones 1984a) may be difficult.

The close association between young kelp perch and the surface canopy of Macrocystis pyrifera is consistent with the assumption that smaller organisms experience greater predation risk (Werner \& Gilliam 1984); young fish should occupy more structurally complex habitats as refuge or in some way balance predation risk and foraging rate (Cerri \& Fraser 1983, Werner et al. 1983, Ebeling \& Laur 1985, Schmitt \& Holbrook 1985, Holbrook \& Schmitt 1988a, b). In this study, the densities of kelp bass and kelp perch were negatively related, and observations and experiments have demonstrated that the kelp bass does prey readily on young kelp perch (Anderson 1993). Furthermore, the presumption that the surface kelp canopy provides an important refuge to young kelp perch is strengthened by the fact that small juveniles are mainly planktivorous. Young fish $<45$ to $50 \mathrm{~mm} \mathrm{SL}$ derive at least 65 to
$70 \%$ (by weight) of their prey from the water column (Anderson 1993). In addition, shade produced by the canopy also may reduce the visibility of young kelp perch to predators (Helfman 1981).

Although Macrocystis pyrifera primarily affects the abundance of kelp perch, other kelps become important when $M$. pyrifera is sparse. Densities of juvenile fish were proportionately higher in the deep-bottom stratum under conditions of sparse cover of the $M$. pyrifera canopy. Laminaria farlowii and Agarum fimbriatum dominate the deep-bottom stratum, where their large blades form horizontal structure that may provide adequate shelter for juveniles. These and other macrophytic habitats may offer protection for kelp perch when physical disturbances such as winter storms (Ebeling \& Laur 1988) or El Niño conditions (Dayton \& Tegner 1984) severely reduce the abundance of $M$. pyrifera.

Species with pelagically dispersed larvae often show tremendous spatial and temporal variability in recruitment to resident reef populations (Doherty \& Williams 1988, Mapstone \& Fowler 1988, Doherty 1991). Surfperches such as the kelp perch are exceptional in that they bear live, fully developed young. This obviates the debate over the relative importance of pre-settlement (Doherty 1991) and post-settlement (Jones 1991) factors to adult population dynamics because kelp perch are born directly into the general reef habitat of adults. Thus, pre-settlement effects are nonexistent, and the abundances of recruits and adults should be more directly linked in the absence of the uncertainty due to variable larval survival in the plankton. Consequently, only post-settlement factors can weaken the direct link between recruits and adults.

Densities of juvenile and adult kelp perch were positively related among reefs within seasons. In this more 'closed' population, adult abundance is determined by factors that affect the cohort of juveniles at local reefs the previous year. However, the relationship between densities of juveniles and that cohort as 1 yr old adults the next year was positive but not significant among reefs or years. The lack of such a relationship suggests either within-reef density-dependent or variable mortality, or among-reef movements of kelp perch.

Variation in Macrocystis pyrifera abundance could have at least 2 major effects masking the juvenileadult relationship. First, a change in macroalgal structure as a refuge may alter juvenile mortality due to predation (Anderson 1993), which would destroy an otherwise consistent pattern of recruitment into the adult population. Second, a reduction in $M$. pyrifera may cause adult fish that feed on kelp-associated prey to leave the area. The results of this study showed a positive relationship between temporal variation in the density of juvenile kelp perch and the percentage 
cover of the $M$. pyrifera canopy among reefs. Moreover, there was a positive relationship between withinreef changes in the density of a cohort of kelp perch and the density of $M$. pyrifera fronds over 1 yr periods.

Although densities of both juvenile and adult kelp perch decreased with time, annual adult densities were more similar at low values, showing less than a 3 fold decrease over the 4 yr period (as compared to an 8 -fold decrease in juveniles). A bottleneck may exist such that variations in juvenile densities are dampened to the extent that they are translated into similar adult densities. One reason for these relatively low but more stable adult numbers could be the presence of limited refuge and a Type III functional response (Murdoch \& Oaten 1975) by a piscivorous predator. According to this type of predatory response, prey populations at low densities have a refuge, physical or otherwise, that reduces predation to a nominal level. As prey numbers rise, however, predation increases dramatically as the per capita refuge resource necessarily declines (i.e. density-dependent mortality). The kelp bass can impact greatly the survival of young, and mortality rates are related to amounts of Macrocystis pyrifera habitat (Anderson 1993). M. pyrifera may provide a physical refuge for kelp perch so that low numbers of fish in the existing kelp structure are relatively safe. Although other factors cannot be ruled out, predation by the kelp bass may be a major factor in determining survival of young to the adult stage.

The kelp bass also exhibits a positive relationship with Macrocystis pyrifera abundance in its first year of life (Carr 1994). Unlike kelp perch, however, the kelp bass has the more complex life cycle of a dispersive planktonic larval phase followed by settlement and recruitment to the resident reef fish population. Nonetheless, Carr (1994) found a significant and positive relationship between the density of young-of-year recruits and the structure of $M$. pyrifera. Moreover, he found a positive relationship between the density of recruits and the density of that cohort as 1 yr old juveniles among reefs and years. At the same time, $M$. pyrifera increased in frond density at reef sites over the 5 yr period (1985 to 1989) of his study. Perhaps this positive relationship was strengthened by greater survival of recruits in increasing densities of $M$. pyrifera, especially if the $1 \mathrm{yr}$ old juveniles tended to remain on these reefs.

By contrast, Macrocystis pyrifera decreased in canopy cover and varied in frond density during the first 3 yr of my study (1989 to 1991) in the same area and at many of the same reefs censused by Carr. Thus, survival of recruits was less assured in the decreasing cover and predators may have been more likely to disrupt the relation between recruits and adults. Furthermore, adult kelp perch, especially females, may move from one reef to another over a long-term period in response to changes in $M$. pyrifera, as they perceive increasing cover as leading to greater breeding success. Indeed, adult densities were positively related to canopy cover which varied among reefs from year to year. Alternatively, however, the relationship simply may be due to differential fish mortality among reefs that vary in cover.

It is not known how fish migrate among reefs. Clumps of floating Macrocystis pyrifera can serve as a vehicle for transport of mostly juvenile fish (Mitchell \& Hunter 1970 ), but the data are sparse and only 1 kelp perch has been found associated with drift $M$. pyrifera. Observations indicate that juvenile kelp perch show strong fidelity to $M$. pyrifera or other laminarian kelps and exhibit fairly restricted movements (Anderson 1993). The abundance of kelp perch in an isolated stand of Pelagophycus porra does suggest, however, that adults may actively search out suitable habitat. In fact, 'dispersal' in surfperch populations may be unlike that of almost all other marine reef fishes. The relatively limited movements of adult females before they release their young may be the primary means by which these fishes colonize reefs. If this is the case, the demography of local surfperch populations are almost entirely determined by factors that affect local juvenile mortality and transition to the adult stage. Such factors may include severe storms that depress the abundance of $M$. pyrifera (Ebeling \& Laur 1988), general trends in the density of $M$. pyrifera (DeMartini \& Roberts 1990), and food abundance as determined by the cover of particular understory algae (Holbrook et al. 1993, in press).

Clearly, the macroalgal assemblages on temperate reefs influence patterns of fish distribution and abundance, at least for several species. What remains is the establishment of more predictive relationships between algal structure and the abundance of reef fishes and the consequences of these relationships to the population dynamics of algal-associated fishes. Variation in the abundance of the kelp perch and other fishes has been linked to variation in algal structure, and this structure may affect the abundance of fishes in several different ways. Macroalgae may act as 'collectors' of larvae, thereby enhancing reef fish recruitment (Carr 1994), provide food resources that determine local fish abundance (Schmitt \& Holbrook 1990 , Holbrook et al. 1993, in press), and increase survival by providing a refuge from predators (Ebeling \& Laur 1985, Carr 1991b, Anderson 1993). However, DeMartini \& Roberts (1990) point out that although they found positive relationships between densities of Macrocystis pyrifera plants and several reef fishes, fish numbers generally fluctuate within particular stands of kelp. During their 2 yr study, densities of $M$. pyrifera declined about $50 \%$ from one year to the next, accompanied by a decrease of about $23 \%$ in total area occu- 
pied by kelp. Unpredictably, this reduction in kelp was accompanied by increases in fish density, possibly due to the lesser areal extent of available kelp habitat. Carr (in press) has examined temperate reef fishes that have differential responses to macroalgal abundance. He suggests that algal abundance, and plant architecture in particular, is a good predictor of fish abundance, as he demonstrated for young-of-year kelp bass (Carr 1994). Such predictability may be true in many instances (also see Jones 1984a, b, Levin 1993), but the replenishment of many marine fish populations from planktonic larval supplies may vary such that at times when fish populations experience poor recruitment or general recruitment failure, previously predictive relationships between algae and fish will disappear. The lack of a larval dispersive stage in surfperches may result in relationships between some species and macroalgae (Ebeling \& Laur 1985, Holbrook et al. 1990, 1993, in press, Schmitt \& Holbrook 1990) that are more predictable, but evidence of this was not confirmed here. A meaningful comparison of macroalgal structure and recruitment strength between fishes with different life histories requires that recruitment of various species be measured concurrently under similar environmental conditions and fluctuations in macroalgal abundance. Moreover, the particular relationships between recruiting species and the structural features of macroalgae must be considered (Carr in press). Further studies of the effects of macroalgae on temperate reef fishes, especially those that focus on recruitment (Jones 1984a, b, Carr 1991a, 1994, Levin 1993, 1994), should increase our understanding of the population consequences of such relationships.

Acknowledgements. I thank M. Brzezinski, M. Carr, A. Ebeling, S. Holbrook, R. Warner and 3 anonymous reviewers for their critical reviews and improvements of the manuscript. I also thank the many assistants who provided diving support, including T. Allison, G. Catalano, T Henry, J. Miner, B. Seibel, J. Shinbashi, M. Tarsa, and V. Vredenburg. M. Carr contributed valuable advice in the field, and P. Raimondi and R. Warner offered suggestions on multiple regression analyses. Logistic support was supplied by the staff of the Catalina Marine Science Center. Financial support was provided by the Electric Power Research Institute Fellowship Program, Southern California Edison (Contract No. C0729903 to A. Ebeling), a University of California Regents Fellowship, and the Lerner-Gray Fund for Marine Research of the American Museum of Natural History. This is Contribution No. 164 of the Wrigley Marine Science Center at Catalina.

\section{LITERATURE CITED}

Anderson, T. W. (1993). An evaluation of density dependence in a marine temperate reef fish: competitive and predatory effects. Ph.D. dissertation, University of California, Santa Barbara

Baltz, D. M. (1984). Life history variation among female surfperches (Perciformes: Embiotocidae). Environ. Biol. Fish.
10: $159-171$

Bodkin, J. L. (1986). Fish assemblages in Macrocystis and Nereocystis kelp forests off central California. Fish. Bull. U.S. $84: 799-807$

Bodkin, J. L. (1988). Effects of kelp forest removal on associated fish assemblages in central California. J. exp. mar. Biol. Ecol. 117: 227-238

Bray, R. N., Ebeling, A. W. (1975). Food, activity, and habitat of three 'picker-type' microcarnivorous fishes in the kelp forests off Santa Barbara, California. Fish. Bull. U.S. 73: $815-829$

Carr, M. H. (1989). Effects of macroalgal assemblages on the recruitment of temperate zone reef fishes. J. exp. mar. Biol. Ecol. 126: 59-76

Carr, M. H. (1991a). Habitat selection and recruitment of an assemblage of temperate zone reef fishes. J. exp. mar. Biol. Ecol. 146: 113-137

Carr, M. H. (1991b). Patterns, mechanisms and consequences of recruitment of a marine temperate reef fish. Ph.D. dissertation, University of California, Santa Barbara

Carr, M. H. (1994). Effects of macroalgal dynamics on recruitment of a temperate reef fish. Ecology 75: 1320-1333

Carr, M. H. (in press). Predicting the recruitment of temperate reef fishes in response to changes in macrophyte density caused by disturbance. In: Stouder, D. J., Fresh, K. L. (eds.) Theory and application in the feeding ecology of fishes. Belle Baruch Mar. Inst. Ser. University of South Carolina Press, Columbia

Cerri, R. D., Fraser, D. F. (1983). Predation and risk in foraging minnows: balancing conflicting demands. Am. Nat. 121. $552-561$

Coyer, J. A. (1979). The invertebrate assemblage associated with Macrocystis pyrifera and its utilization as a food resouce by kelp forest fishes. Ph.D. dissertation, University of Southern California, Los Angeles

Davis, G. E., Anderson, T. W. (1989). Population estimates of four kelp forest fishes and an evaluation of three in situ assessment techniques. Bull. mar. Sci. 44: 1138-1151

Dayton, P. K. (1985). Ecology of kelp communities. A. Rev. Ecol. Syst. 16: 215-245

Dayton, P. K., Tegner, M. J. (1984). Catastrophic storms, El Niño, and patch stability in a southern California kelp community. Science 224: 283-285

DeMartini, E. E., Roberts, D. A. (1990). Effects of giant kelp (Macrocystis) on the density and abundance of fishes in a cobble-bottom kelp forest. Bull. mar. Sci. 46: 287-300

Doherty, P. J. (1991). Spatial and temporal patterns in recruitment. In: Sale, P. F. (ed.) The ecology of coral reef fishes. Academic Press, San Diego, p. 261-293

Doherty, P. J., Williams, D. McB. (1988). The replenishment of coral reef fish populations. Oceanogr. mar. Biol. A. Rev. 26 : $487-551$

Ebeling, A. W., Hixon, M. A. (1991). Tropical and temperate reef fishes: comparison of community structures. In: Sale, P. F. (ed.) The ecology of coral reef fishes. Academic Press, San Diego, p. 509-563

Ebeling, A. W., Larson, R. J., Alevizon, W. S. (1980a). Habitat groups and island-mainland distribution of kelp-bed fishes off Santa Barbara, California. In: Power, D. M. (ed.) The California islands: proceedings of a multidisciplinary symposium. Santa Barbara Museum of Natural History, Santa Barbara, p. 403-431

Ebeling, A. W., Larson, R. J., Alevizon, W. S., Bray, R. N. (1980b). Annual variability of reef-fish assemblages in kelp forests off Santa Barbara, California. Fish. Bull. U.S. 78: $361-377$

Ebeling, A. W., Laur, D. R. (1985). The influence of plant cover 
on surfperch abundance at an offshore temperate reef. Environ. Biol. Fish. 16: 123-133

Ebeling, A. W., Laur, D. R. (1988). Fish populations in kelp forests without sea otters: effects of severe storm damage and destructive sea urchin grazing. In: VanBlaricom, G. R., Estes, J A. (eds.) the community ecology of sea otters, Ecological studies 65. Springer-Verlag, Berlin, p. 169-191

Greig-Smith, P. (1983). Quantitative plant ecology, 3rd edn. University of California Press, Berkeley

Helfman, G. S. (1981). The advantage to fishes of hovering in shade. Copeia 2: $392-400$

Hocking, R. R. (1976). The analysis and selection of variables in linear regression. Biometrics 32: 1-49

Holbrook, S. J., Carr, M. H., Schmitt, R. J., Coyer, J. A. (1990). The effect of giant kelp on local abundance of demersal fishes: the importance of ontogenetic resource requirements. Bull. mar. Sci. 47: 104-114

Holbrook, S. J., Kingsford, M. J., Schmitt, R. J., Stephens J. S. $\mathrm{Jr}$ (in press). Spatial and temporal patterns in assemblages of temperate reef fish. Am. Zool

Holbrook, S. J., Schmitt, R. J. (1988a). Effects of predation risk on foraging behavior: mechanisms altering patch choice. J. exp. mar. Biol. Ecol. 121: 151-163

Holbrook, S. J., Schmitt, R. J. (1988b). The combined effects of predation risk and food reward on patch selection. Ecology 69: $125-134$

Holbrook, S. J., Swarbrick, S. I., Schmitt, R. J., Ambrose, R. F. (1993). Reef architecture and reef fish: correlations of population densities with attributes of subtidal rocky environments. Proc. 2nd int. Temperate Reef Symp., p. 99-106

Hubbs, C. L., Hubbs, L. C. (1954). Data on the life history, variation, ecology, and relationships of the kelp perch, Brachyistius frenatus, an embiotocid fish of the Californias. Calif. Fish Game 40: 183-198

Jones, G. P. (1984a). Population ecology of the temperate reef fish Pseudolabrus celidotus Block \& Schneider (Pisces: Labridae). I. Factors influencing recruitment. J. exp. mar. Biol. Ecol. 75: 257-276

Jones, G. P. (1984b). The influence of habitat and behavioural interactions on the local distribution of the wrasse, Pseudolabrus celidotus. Environ. Biol. Fish. 10: 43-58

Jones, G. P. (1991). Postrecruitment processes in the ecology of coral reef fish populations: a multifactorial perspective. In: Sale, P. F. (ed.) The ecology of coral reef fishes. Academic Press, San Diego, p. 294-328

Larson, R. J., DeMartini, E. E. (1984). Abundance and vertical distribution of fishes in a cobble-bottom kelp forest off San Onofre, California. Fish. Bull. U.S. 82: 37-53

Levin, P. S. (1993). Habitat structure, conspecific presence and spatial variation in the recruitment of a temperate reef fish. Oecologia 94:176-185

Levin. P. S. (1994). Fine-scale temporal variation in recruitment of a temperate demersal fish: the importance of settlement versus post-settlement loss. Oecologia 97 : $124-133$

Limbaugh, C. (1955). Fish life in the kelp beds and the effects of kelp harvesting. IMR Ref. 55-9. University of California Institute of Marine Resources, La Jolla

Lincoln Smith, M. P. (1989). Improving multispecies rocky reef fish censuses by counting different groups of species using different procedures. Environ. Biol. Fish. 26: 29-37

Mallows, C. L. (1973). Some comments on $C_{p}$. Technometrics 15: $661-675$

This article was submitted to the editor
Mapstone, B. D., Fowler, A. J. (1988). Recruitment and the structure of assemblages of fish on coral reefs. Trends Ecol. Evol. 3: 72-77

McCormick, M. I., Choat, J. H. (1987). Estimating total abundance of a large temperate-reef fish using visual striptransects. Mar. Biol. 96: 469-478

Mitchell, C. T. Hunter, J. R. (1970). Fishes associated with drifting kelp, Macrocystis pyrifera, off the coast of southern California and northern Baja California. Calif. Fish Game 56: 288-297

Moreno, C. A., Jara, H. F. (1984). Ecological studies on fish fauna associated with Macrocystis pyrifera belts in the south of Fuegian Islands, Chile. Mar. Ecol. Prog. Ser. 15: 99-107

Mosteller, F., Tukey, J. W. (1977). Data analysis and regression. Addison-Wesley, Reading, MA

Murdoch, W. W., Oaten, A. (1975). Predation and population stability. Adv. Ecol. Res. 9: 1-132

Nisbet, R. M., Bence, J. R. (1989). Alternative dynamic regimes for canopy-forming kelp: a variant on densityvague population regulation. Am. Nat. 134: 377-408

Patton, M. L., Grove, R. S., Harman, R. F. (1985). What do natural reefs tell us about designing artificial reefs in southern California? Bull. mar. Sci. 37: 279-298

Quast, J. C. (1968). Fish fauna of the rocky inshore zone. In: North, W. J., Hubbs, C. L. (eds.) Utilization of kelp-bed resources in southern California. Calif. Dept. Fish Game, Fish Bull. 139, p. 35-55

Sale, P. F., Douglas, W. A. (1981). Precision and accuracy of visual census technique for fish assemblages on coral patch reefs. Environ. Biol. Fish. 6: 333-339

SAS Institute, Inc. (1988). SAS/STAT user's guide, Release 6.03 edn. SAS Institute, Inc, Cary, NC

Schiel, D. R., Foster, M. S. (1986). The structure of subtidal algal stands in temperate waters. Oceanogr. mar. Biol. A Rev. 24: 265-307

Schmitt, R. J., Holbrook, S. J. (1985). Patch selection by juvenile black surfperch (Embiotocidae) under variable risk interactive influence of food quality and structural complexity. J. exp. mar. Biol. Ecol. 85: 269-285

Schmitt, R. J., Holbrook, S. J (1990). Contrasting effects of giant kelp on dynamics of surfperch populations. Oecologia 84: $419-429$

Stephens, J. S. Jr, Morris, P. A., Zerba, K. E. (1984). Factors affecting fish diversity on a temperate reef: the fish assemblage of Palos Verdes Point, 1974-1981. Environ. Biol. Fish. 11: 259-275

Warner, R. R., Chesson, P. L. (1985). Coexistence mediated by recruitment fluctuations: a field guide to the storage effect. Am. Nat. 125: $769-787$

Werner, E. E., Gilliam, J. F. (1984). The ontogenetic niche and species interactions in size-structured populations. A. Rev. Ecol. Syst. 15: 393-425

Werner, E. E., Gilliam, J. F., Hall, D. J., Mittelbach, G. G. (1983). An experimental test of the effects of predation risk on habitat use in fish. Ecology 64: 1540-1548

Winer, B. J. (1971). Statistical principles in experimental design, 2nd edn. McGraw-Hill, Kogakusha

Womersley, H. B. S. (1954). The species of Macrocystis with special reference to those on southern Australian coasts. Univ. Calif. Publ. Bot. 27: 109-132

Zar, J. H. (1984). Biostatistical analysis. Prentice Hall, Englewood Cliffs, NJ

Manuscript first received: August 31, 1993

Revised version accepted: August 2, 1994 